\title{
Identifikasi Pencemaran Logam Berat dan Hubungannya dengan Suseptibilitas Magnetik pada Sedimen Sungai Batang Ombilin Kota Sawahlunto
}

\author{
Diana Putri*, Afdal \\ Jurusan Fisika FMIPA Universitas Andalas \\ Kampus Unand, Limau Manis, Padang, 25163 \\ *putri.diana032@gmail.com
}

\begin{abstract}
ABSTRAK
Telah dilakukan penelitian untuk menentukan kandungan logam berat dan suseptibilitas magnetik serta hubungan keduanya pada sedimen Sungai Batang Ombilin Kota Sawahlunto. Pengambilan sampel dilakukan pada bulan September 2017 pada 15 titik dengan jarak antar titik adalah 500 meter. Pengukuran suseptibilitas magnetik menggunakan Bartington Magnetic Suseptibility Meter dengan sensor MS2B. Hasil menunjukkan nilai suseptibilitas magnetik sedimen sungai di lokasi penelitian relatif tinggi yaitu berkisar antara $285,71 \times 10^{-8} \mathrm{~m}^{3} / \mathrm{kg}$ sampai $2664,63 \times 10^{-8} \mathrm{~m}^{3} / \mathrm{kg}$. Tingginya Nilai suseptibilitas magnetik disebabkan oleh tingginya kandungan $\mathrm{Fe}_{2} \mathrm{O}_{3}(5,11 \%)$. Sepuluh sampel dipilih untuk dilakukan uji XRF. Konsentrasi rata-rata logam berat pada sedimen Sungai Batang Ombilin sudah melebihi ambang batas yang ditetapkan, yaitu Cr (143 ppm), Mn (1897 ppm), Fe (96181 ppm), Ni (24 ppm), Cu (145 ppm), $\mathrm{Zn}(343 \mathrm{ppm})$, As (38 ppm) dan $\mathrm{Pb}(53 \mathrm{ppm})$. Hal ini mengindikasikan tingginya tingkat pencemaran logam berat pada sedimen Sungai Batang Ombilin. Nilai suseptibilitas magnetik dan kandungan logam berat memiliki nilai korelasi yang cukup rendah dengan koefisien korelasi $-0,46$. Hal ini menandakan logam berat tidak berkontribusi besar terhadap nilai suseptibilitas magnetik, melainkan ada faktor lain yang berkontribusi seperti keadaan geologi, sedimentasi dan keberadaan mineral magnetik.

Kata kunci: Sedimen sungai, logam berat, suseptibilitas magnetik, Bartington Magnetic Suseptibility Meter sensor MS2B, X-Ray Fluoresence
\end{abstract}

\begin{abstract}
The heavy metal content and magnetic susceptibility and their relation on sediment of Batang Ombilin river Sawahlunto has been investigated. Samples were collected in September 2017 at 15 points with 500 meters distance. Magnetic susceptibility was measured using Bartington Magnetic Suseptibility Meter with MS2B sensor. The results show that the magnetic susceptibility value of river sediments are relatively high, range from $285.71 \times 10^{-8} \mathrm{~m}^{3} / \mathrm{kg}$ to $2664.63 \times 10^{-8} \mathrm{~m}^{3} / \mathrm{kg}$. High magnetic susceptibility values are possibly caused by high content of $\mathrm{Fe}_{2} \mathrm{O}_{3}(5.11 \%)$. Ten samples were selected for XRF test. The average concentration of heavy metals in river sediments has exceeded the standard values, those are Cr (143 ppm), Mn (1897 ppm), Fe (96181 ppm), Ni (24 ppm), Cu (145 ppm), Zn (343 ppm), As (38 ppm) and $\mathrm{Pb}(53 \mathrm{ppm})$. The high values indicate the high level of heavy metal pollution on the Batang Ombilin river sediment. Magnetic susceptibility has low correlation with a heavy metal contents with correlation is 0.46. This indicate that heavy metals do not contribute significantly to the magnetic susceptibility value, but there are other factors such as geological condition, sedimentation and magnetic mineral composition.

Keywords: River sediment, heavy metal, magnetic susceptibility, Bartington Magnetic Suseptibility Meter with sensor MS2B, X-Ray Fluoresence
\end{abstract}

\section{PENDAHULUAN}

Sungai merupakan salah satu media yang sering tercemar oleh logam berat. Menurut Sudarwin (2008), keberadaan logam berat dalam sungai terutama berasal dari hasil limbah industri, selain dari itu logam berat yang berasal dari sumber alamiah juga dapat masuk ke dalam perairan melalui pengikisan batuan mineral. Adanya logam berat di perairan dapat berbahaya baik secara langsung terhadap kehidupan organisme, maupun efeknya secara tidak langsung terhadap kesehatan manusia.

Logam berat yang ada pada perairan lama-kelamaan akan turun dan mengendap pada dasar perairan membentuk sedimen. Apabila akumulasi logam berat di sedimen terangkut kembali ke permukaan air, maka hal ini akan mengakibatkan penurunan kualitas air sungai sehingga sungai tidak dapat digunakan sesuai peruntukannya (Erlanda, 2012). Konsentrasi logam berat pada sedimen sungai cukup tinggi jika dibandingkan dengan konsentrasi logam berat pada air sungai (Rochyatun dan Rozak, 2007) sehingga sedimen menjadi indikator yang 
penting untuk melihat pencemaran sungai yang diakibatkan logam berat (Wang dkk., 2014; Xu dkk., 2014).

Metode yang biasa digunakan untuk mengetahui adanya logam berat pada sedimen adalah metode geokimia dengan menggunakan alat Atomic Absorbtion Spectroscopy (AAS) dan X-Ray Fluorosence (XRF). Metode ini akurat untuk mengetahui jenis dan komposisi zat pencemar yang terdapat pada suatu bahan, namun memerlukan waktu yang lama dan biaya yang mahal (Sudarningsih dkk, 2013). Untuk efisiensi waktu dan biaya, maka diperlukan metode pendahuluan untuk mengidentifikasi adanya zat pencemar seperti logam berat dalam suatu bahan. Metode pendahuluan yang telah dikembangkan dalam mengidentifikasi adanya logam berat adalah metode magnetik. Pada metode magnetik, identifikasi adanya logam berat dalam suatu bahan dapat ditentukan melalui pengukuran suseptibilitas magnetik. Logam berat pada umumnya merupakan mineral magnetik dengan nilai suseptibilitas magnetik yang tinggi. Tanah yang mengandung logam berat akan memiliki nilai suseptibilitas yang lebih tinggi daripada tanah yang tidak mengandung logam berat (Yulius dan Afdal, 2014).

Sungai Batang Ombilin merupakan salah satu sungai yang berada di Kota Sawahlunto. Sungai ini berhulu di Danau Singkarak, alirannya mengalir dari utara ke selatan yaitu dari Desa Talawi ke Desa Rantih Kecamatan Talawi dan bermuara hingga memasuki Provinsi Riau (Mindasari, 2007). Sungai Batang Ombilin telah dimanfaatkan masyarakat sebagai sumber air untuk berbagai kepentingan seperti irigasi, PDAM, sumber air baku untuk proses pemisahan batubara dan proses penguapan air sebagai penggerak turbin PLTU (Purba dkk., 2015).

Berdasarkan Aspek Buku Puth Sanitasi Kota Sawahlunto (2011) tentang kondisi sanitasi Kota Sawahlunto, permasalah utama pencemaran di Sungai Batang Ombilin adalah tingginya pembuangan limbah dari pemukiman, industri PLTU, PDAM, pertambangan emas, batubara dan pasir besi ke badan sungai. Ini karena belum adanya saluran khusus untuk pembuangan limbah pabrik dan sarana pengelolaan air limbah. Hal ini memberikan kontribusi dalam pencemaran sungai karena sangat mungkin limbah buangan tersebut mengandung polutan berupa logam berat. Logam-logam berat yang biasa ditemukan dari kegiatan pertambangan seperti $\mathrm{Pb}, \mathrm{Cr}, \mathrm{Cu}, \mathrm{Ni}, \mathrm{Zn}$ dan $\mathrm{Cd}$ (Danielowska, 2006). Logam-logam yang terbawa arus ke dalam aliran Sungai Batang Ombilin akan mengalami pengendapan atau sedimentasi.

Mengingat potensi logam berat pada sedimen sungai sebagai salah satu sumber pencemar bagi air sungai, maka perlu dilakukan pemantuan terhadap sungai tersebut. Namun sejauh ini belum pernah dilakukan penelitian terhadap sedimen Sungai Batang Ombilin. Oleh karena itu, dilakukan penelitian untuk mengidentifikasi sebaran logam berat pada sedimen Sungai Batang Ombilin kota Sawahlunto.

\section{METODE}

Penelitian dilaksanakan mulai bulan April hingga Desember 2017. Penelitian dilaksanakan di Laboratorium Fisika Bumi, Jurusan Fisika Universitas Andalas dan Laboratorium Instrumentasi, Jurusan Kimia Universitas Negeri Padang. Lokasi yang menjadi objek penelitian adalah sedimen sungai Batang Ombilin Kota Sawahlunto pada 15 titik dengan jarak antar titik sampel adalah 500 meter (Gambar 1). Sampel diambil pada kedalaman sepuluh sentimeter sebanyak $10 \mathrm{~g}$ menggunakan pipa PVC pada tiap-tiap titik, pengambilan sampel dilakukan. Pengukuran suseptibilitas magnetik dilakukan di Laboratorium Fisika Bumi menggunakan alat Bartington Magnetic Susceptibility Meter MS2 dengan sensor MS2B. Kandungan logam berat yang terkandung dalam sampel diukur dengan metode X-Ray Fluoresence (XRF). 


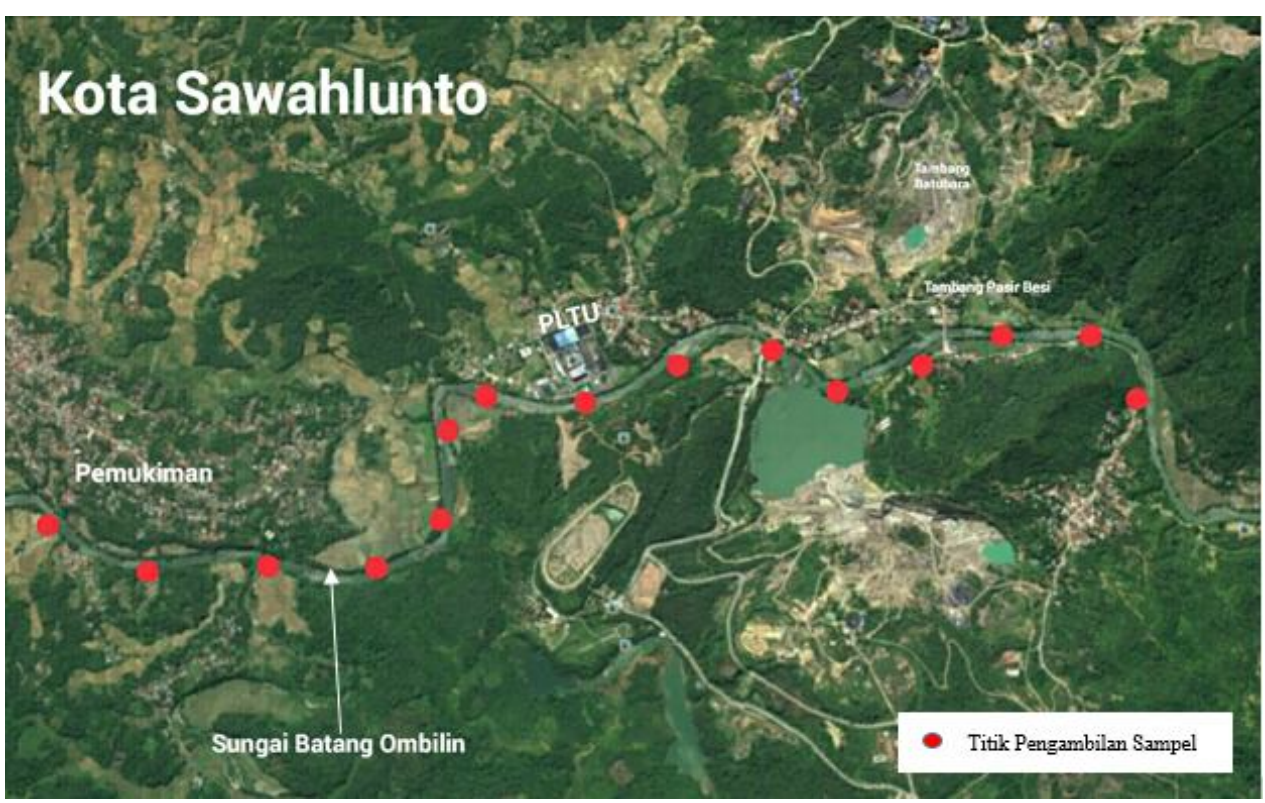

Gambar 1. Lokasi Pengambilan Sampel

\section{HASIL DAN DISKUSI}

\subsection{Suseptibilitas Magnetik Sedimen Sungai Batang Ombilin}

Data suseptibilitas magnetik dapat dilihat pada Tabel 1. Nilai suseptibilitas magnetik sedimen berkisar antara $285,71 \times 10^{-8} \mathrm{~m}^{3} / \mathrm{kg}$ sampai $2664,63 \times 10^{-8} \mathrm{~m}^{3} / \mathrm{kg}$ dengan rata-rata $1153,23 \times 10^{-8} \mathrm{~m}^{3} / \mathrm{kg}$. Beberapa hal yang dapat mempengaruhi nilai suseptiblitas magnetik adalah area geologi, sedimentasi, dan kandungan mineral magnetik (Kucer, 2012).

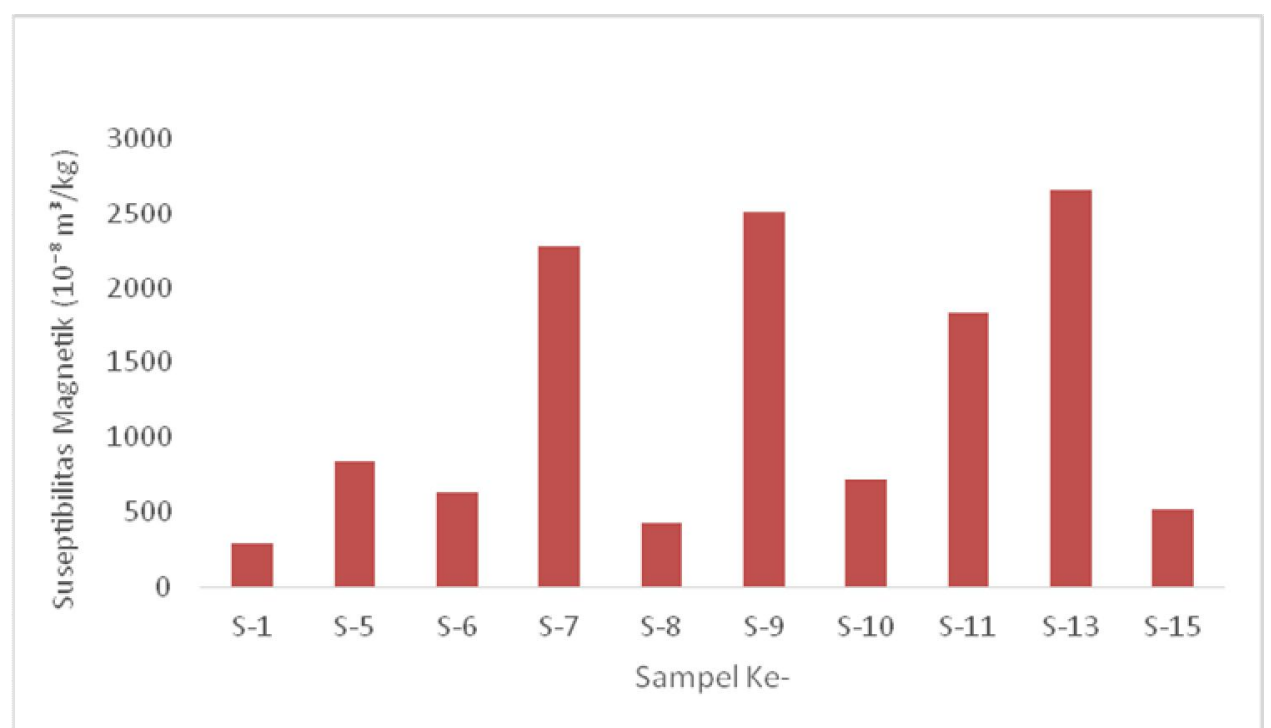

Gambar 2. Perubahan nilai suseptibilitas magnetik terhadap lokasi titik sampel

Gambar 2 memperlihatkan nilai suseptibilitas magnetik sedimen Sungai Batang Ombilin yang fluktuatif namun cenderung meningkat dari hulu hingga hilir sungai. Hal ini mengindikasikan adanya perbedaan kuantitas mineral magnetik dalam sedimen sungai, dimana kandungan mineral magnetik semakin ke hilir semakin meningkat. Pada Tabel 1 dapat dilihat nilai suseptibilitas magnetik terendah pada sampel S-1 yaitu $285,71 \times 10^{-8} \mathrm{~m}^{3} / \mathrm{kg}$. Hal ini mengindikasikan bahwa kandungan mineral magnetik pada titik tersebut rendah, dimana sampel ini diambil pada daerah pemukiman penduduk, yang diduga limbah yang dihasilkan dari kegiatan rumah tangga tidak mengandung mineral magnetik yang dominan.

Nilai Suseptibilitas magnetik tertinggi pada sampel S-13 yaitu $2664,63 \times 10^{-8} \mathrm{~m}^{3} / \mathrm{kg}$. Hal ini mengindikasikan bahwa kandungan mineral magnetik pada titik tersebut cukup tinggi. Hasil 
uji XRF membuktikan bahwa sampel mengandung mineral magnetik yaitu hematit $\left(\mathrm{Fe}_{2} \mathrm{O}_{3}\right)$. Hal ini dikarenakan sampel ini diambil pada daerah pertambangan pasir besi, dimana kegiatan hasil pertambangan mengandung logam Fe yang tinggi.

Perbedaan nilai suseptibilitas magnetik sedimen yang didapatkan dipengaruhi oleh proses sedimentasi dan area geologi Sungai Batang Ombilin yang berada di kawasan industri PLTU, selain itu sepanjang aliran sungai juga terdapat kegiatan penambangan liar emas, pasir besi dan pemukiman penduduk dimana sungai menjadi tempat pembuangan akhir limbah yang berasal dari kegiatan setempat. Input mineral magnetik yang terbawa melalui proses pembuangan limbah yang kemudian terendapkan akan mempengaruhi nilai suseptibilitas magnetik di sedimen.

\subsection{Kandungan Logam Berat}

Data kandungan logam berat pada sedimen Sungai Batang Ombilin Kota Sawahlunto beserta konsentrasinya dapat dilihat pada Tabel 1 . Kandungan logam berat $\mathrm{Cr}$ di lokasi penelitian hampir merata dengan nilai konsentrasinya berkisar antara 90-250 ppm dan rata-rata $143 \mathrm{ppm}$. Nilai rata-rata konsentrasi logam berat $\mathrm{Cr}$ yang didapatkan di lokasi penelitian telah melebihi ambang batas yang ditetapkan. Dengan demikian maka sedimen sungai pada lokasi penelitian telah tercemar oleh logam berat $\mathrm{Cr}$, karena konsentrasi pada semua titik pengambilan sampel telah melebihi ambang batas yang ditetapkan. Konsentrasi logam berat $\mathrm{Cr}$ dalam sedimen tertinggi $250 \mathrm{ppm}$ pada lokasi sampel S-7 yaitu berada dekat dengan pemukiman penduduk dan industri PLTU.

Tabel 1. Nilai suseptibilitas magnetik dan masing-masing konsentrasi logam berat pada sedimen Sungai Batang Ombilin

\begin{tabular}{|c|c|c|c|c|c|c|c|c|c|c|}
\hline \multirow{2}{*}{$\begin{array}{l}\text { Kode } \\
\text { Sampel }\end{array}$} & \multirow{2}{*}{$\begin{array}{c}\chi \\
\left(\times 10^{-8} \mathrm{~m}^{3}\right. \\
\left.\mathrm{kg}^{-1}\right) \\
\end{array}$} & \multicolumn{9}{|c|}{ Konsentrasi Logam Berat (ppm) } \\
\hline & & $\mathrm{Cr}$ & $\mathrm{Mn}$ & $\mathrm{Fe}$ & $\mathrm{Ni}$ & $\mathrm{Cu}$ & $\mathrm{Zn}$ & As & $\mathrm{Pb}$ & Total \\
\hline S-1 & 285.71 & 110 & 2150 & 87140 & 10 & 180 & 280 & 50 & 50 & 89970 \\
\hline S-5 & 837.59 & 110 & 3280 & 111790 & 0 & 160 & 310 & 30 & 50 & 115730 \\
\hline S-6 & 624.97 & 180 & 1330 & 91360 & 50 & 150 & 440 & 50 & 70 & 93630 \\
\hline S-7 & 2278.03 & 250 & 1380 & 93710 & 40 & 140 & 370 & 30 & 40 & 95960 \\
\hline $\mathrm{S}-8$ & 425.35 & 190 & 1990 & 111900 & 50 & 190 & 330 & 60 & 60 & 114770 \\
\hline S-9 & 2511.71 & 100 & 1150 & 82240 & 0 & 70 & 150 & 10 & 40 & 83760 \\
\hline S-10 & 715.76 & 130 & 4040 & 146330 & 0 & 230 & 430 & 50 & 80 & 151290 \\
\hline S-11 & 1829.56 & 90 & 1210 & 71840 & 0 & 80 & 140 & 10 & 30 & 73400 \\
\hline S-13 & 2664.63 & 140 & 1010 & 79920 & 10 & 90 & 280 & 10 & 50 & 81510 \\
\hline S-15 & 509.82 & 130 & 1430 & 85580 & 30 & 160 & 700 & 80 & 60 & 88170 \\
\hline \multicolumn{2}{|c|}{ Rata-rata } & 143 & 1897 & 96181 & 24 & 145 & 343 & 38 & 53 & 98819 \\
\hline \multicolumn{2}{|c|}{ Nilai Maksimum } & 250 & 4040 & 111900 & 50 & 230 & 700 & 80 & 80 & 151290 \\
\hline \multicolumn{2}{|c|}{ Nilai Minimum } & 90 & 1010 & 71840 & 0 & 70 & 140 & 10 & 30 & 73400 \\
\hline \multicolumn{2}{|c|}{ Ambang Batas } & $80^{(\mathrm{a})}$ & $248,77^{(\mathrm{b})}$ & $20^{(\mathrm{c})}$ & $21^{(\mathrm{a})}$ & $108^{(\mathrm{d})}$ & $271^{(\mathrm{d})}$ & $20^{(\mathrm{a})}$ & $36,8^{(\mathrm{d})}$ & \\
\hline
\end{tabular}

(a) ANZECC Interm Sediment Quality Guidlines (ISQG) (2000)

(b) National Sediment Quality Survey US EPA (2004)

(c) Sediment Quality Guideline Values for Metals and Associated Levels of Concern to be used in Doing Assessments of Sediment Quality (2003)

(d) KMNLH (2010)

Kandungan logam berat Mn di lokasi penelitian berkisar antara 1010-4040 ppm dengan rata-rata $1897 \mathrm{ppm}$. Konsentrasi rata-rata hasil penelitian relatif tinggi. Hal ini menujukkan bahwa sedimen sungai pada lokasi penelitian tercemar logam berat Mn karena seluruh nilai konsentrasi logam berat Mn yang didapatkan relatif jauh lebih tinggi dibandingkan dengan nilai ambang batasnya. Konsentrasi logam berat Mn dalam sedimen tertinggi 4040 ppm pada lokasi 344 
sampel S-10 yaitu daerah pertambangan liar batubara, dimana bahan-bahan beracun yang ditinggalkan dari pertambangan dan pengolahan batubara mengandung logam berat salah satunya mangan $(\mathrm{Mn})$.

Kandungan logam berat Fe yang didapatkan di lokasi penelitian relatif sangat tinggi dibandingkan dengan nilai ambang batasnya. Hal ini menujukkan bahwa sedimen sungai batang ombilin telah tercemar logam berat Fe. Tingginya konsentrasi total logam Fe ini disebabkan karena sepanjang lokasi penelitian merupakan daerah penambangan pasir besi yang mana mengindikasikan tingginya kandungan pasir besi di sungai Batang Ombilin. Kandungan logam berat Ni di lokasi penelitian tidak merata, pada beberapa titik tidak terdapat logam berat $\mathrm{Ni}$ (S1, S-9, S-10 dan S-11). Jika dibandingkan dengan ambang batas logam Ni dalam sedimen, maka konsentrasi logam berat Ni di lokasi penelitian yang telah melebihi ambang batas yaitu pada sampel S-6, S-7, S-8, dan S-15. Lokasi tersebut berada dekat dengan pemukiman penduduk dan industri setempat.

Konsentrasi logam berat $\mathrm{Cu}$ yang didapatkan di lokasi penelitian ini relatif tinggi dibandingkan penelitian yang dilakukan Edward $(2010,2011)$ yang mendapatkan kadar Cu ratarata di perairan Maluku Tenggara yang relatif tidak tercemar, yakni di Elat 0,0067 ppm, di Ohiomas 0,251 ppm dan di Ngilngof 0,039 ppm. Jika dibandingkan dengan ambang batas logam $\mathrm{Cu}$ dalam sedimen, maka konsentrasi logam berat $\mathrm{Cu}$ di lokasi penelitian pada titik pengambilan sampel S-9, S-11 dan S-13 saja yang tidak tercemar logam berat $\mathrm{Cu}$, sedangkan pada titik sampel yang lain diketahui konsentrasi logam berat $\mathrm{Cu}$ sudah melebihi ambang batas atau dikatakan tercemar.

Konsentrasi logam berat $\mathrm{Zn}$ pada lokasi penelitian hanya pada titik pengambilan sampel S-9 dan S-11 d saja yang tidak tercemar logam berat Zn, sedangkan pada titik sampel yang lain diketahui konsentrasi logam berat $\mathrm{Zn}$ sudah melebihi ambang batas atau dikatakan tercemar. Kandungan logam berat As di lokasi penelitian hampir merata. Pada titik pengambilan sampel S-9 dan S-11 dan S-13 saja yang tidak tercemar logam berat As, sedangkan pada titik sampel yang lain diketahui konsentrasi logam berat As sudah melebihi ambang batas atau dikatakan tercemar.

Konsentrasi logam berat $\mathrm{Pb}$ yang didapatkan di lokasi penelitian ini relatif tinggi dibandingkan Edward $(2010,2011)$ yang mendapatkan kadar Pb rata-rata di perairan Maluku Tenggara yang relatif tidak tercemar, yakni di Elat 0,042 ppm, di Ohiomas 3,376 ppm, dan di Ngilngof 3,352 ppm, sedangkan konsentrasi logam berat $\mathrm{Pb}$ rata-rata alami yang terdapat di permukaan bumi adalah < 12,5 ppm (Odat dan Alshammara, 2011). Jika dibandingkan dengan nilai ambang batas logam $\mathrm{Pb}$ dlam sedimen, maka hampir seluruh titik pengambilan sampel telah tercemar oleh logam Fe kecuali pada sampel S-11 saja yang tidak tercemar logam berat $\mathrm{Pb}$.

\subsection{Hubungan Suseptibilitas Magnetik dengan Konsentrasi Logam Berat}

Pada Gambar 3. dapat dilihat hubungan suseptibilitas magnetik dengan kandungan logam berat total pada lokasi penelitian. Koefisien korelasi logam berat yang didapatkan cukup rendah yaitu $-0,46$. Hal ini menandakan kandungan logam berat tidak berkontribusi besar terhadap nilai suseptibilitas magnetik, melainkan ada faktor lain yang berkontribusi seperti keadaan geologi, sedimentasi. Selain itu rendahnya korelasi antara persentase unsur logam berat dengan suseptibilitas magnetik dimungkinkan karena logam berat yang ada tidak membentuk mineral ferromagnetik yang dominan (Wahyuni dkk., 2015).

Sebaliknya nilai suseptibilitas sampel yang didapatkan relatif tinggi, hal ini diperkirakan karena semua sampel mengandung mineral magnetik yaitu hematit ( $\mathrm{Fe} 2 \mathrm{O} 3$ ) yang tinggi, dibuktikan dengan kandungan rata-rata $\mathrm{Fe}_{2} \mathrm{O}_{3}$ yang didapatkan dari Uji XRF sebesar

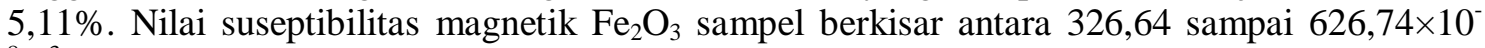
${ }^{8} \mathrm{~m}^{3} / \mathrm{kg}$. Di sepanjang aliran sungai Batang Ombilin juga dilakukan penambangan pasir besi yang menunjukkan tingginya kandungan Logam $\mathrm{Fe}$ di lokasi sekitar. Konsentrasi unsur $\mathrm{Fe}$ relatif jauh lebih tinggi di setiap lokasi dibandingkan konsentrasi logam berat lainnya. Akibatnya suseptibilitas magnetik akan bertambah dalam jumlah yang besar. 


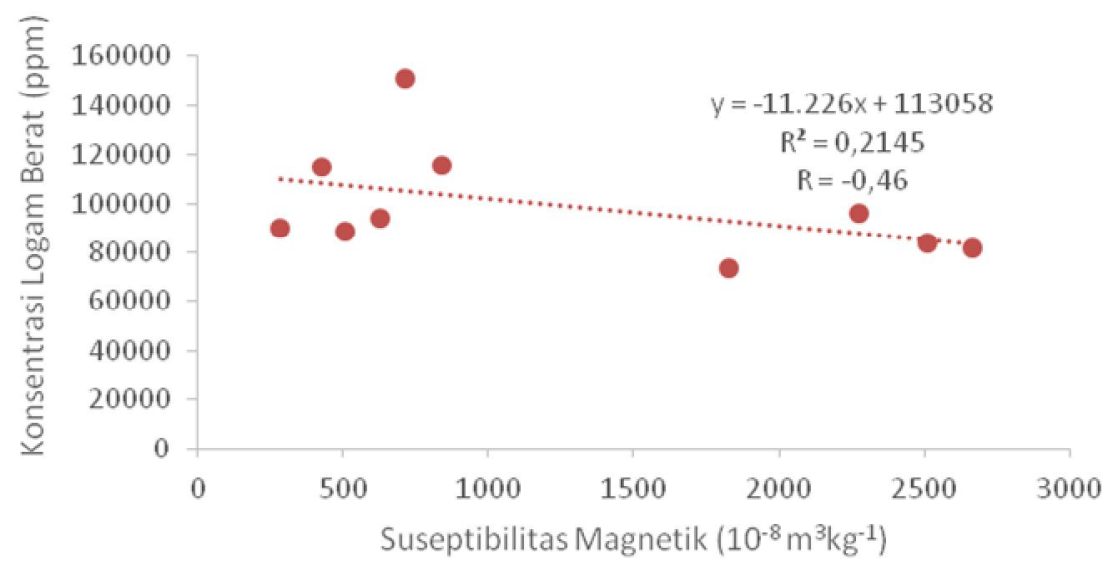

Gambar 3. Hubungan suseptibilitas magnetik dengan masing-masing logam berat.

\section{KESIMPULAN}

Berdasarkan hasil penelitian yang telah didapatkan, dapat disimpulkan bahwa, lima belas sampel sedimen pada lokasi penelitian memiliki nilai suseptibilitas magnetik yang cukup tinggi, berkisar antara $285,71 \times 10^{-8} \mathrm{~m}^{3} / \mathrm{kg}$ sampai $2664,63 \times 10^{-8} \mathrm{~m}^{3} / \mathrm{kg}$ dengan rata-rata $1153,23 \times 10^{-8} \mathrm{~m}^{3} / \mathrm{kg}$. Nilai suseptibilitas magnetik yang tinggi dimungkinkan karena sedimen di dominasi oleh kandungan mineral oksida $\left(\mathrm{Fe}_{2} \mathrm{O}_{3}\right)$. Hasil uji XRF menunjukan Unsur-unsur logam berat yang terkandung dalam sedimen meliputi $\mathrm{Cr}, \mathrm{Mn}, \mathrm{Fe}, \mathrm{Ni}, \mathrm{Cu}, \mathrm{Zn}, \mathrm{As}$ dan $\mathrm{Pb}$ dan sampel di dominasi oleh kandungan $\mathrm{Fe}_{2} \mathrm{O}_{3}(5,11 \%)$. Konsentrasi rata-rata logam berat pada sedimen Sungai Batang Ombilin sudah melebihi ambang batas yang ditetapkan yaitu, $\mathrm{Cr}$ (143 ppm), Mn (1897 ppm), Fe (96181 ppm), Ni (24 ppm), Cu (145 ppm), Zn (343), As (38ppm) dan $\mathrm{Pb}(53 \mathrm{ppm})$. Hal ini mengindikasikan tingginya tingkat pencemaran logam berat pada Sungai Batang Ombilin. Nilai koefisien korelasi suseptibilitas magnetik dengan kandungan logam berat pada sampel yang didapatkan cukup rendah yaitu $-0,46$. Hal ini menandakan logam berat tidak berkontribusi besar terhadap nilai suseptibilitas magnetik, melainkan ada faktor lain yang berkontribusi seperti keadaan geologi, sedimentasi dan komposisi mineral magnetik.

\section{DAFTAR PUSTAKA}

BAPPEDA Kota Sawahlunto, 2011, BPS Kota Sawahlunto, BAPPEDA Kota Sawahlunto, Sawahlunto Sumatera Barat.

Erlanda, E.P., 2012, Kajian Sedimentasi pada Sumber Air Baku PDAM Kota Pontianak, Jurnal Teknik Sipil UNTAN, Vol.12, No.2.

Danielowska, D.S., 2006, Heavy Metals in Fly Ash from a Coal-Fired Power Station in Poland, Polish Journal of Environmental Study, Vol. 15, No. 6, hal. 943-946.

KMNLH, 2010, State environment minister's decision draft, http://www.klh.go.id, Diakses Tanggal 16 November 2017.

Kucer, N., Sadikoglu, I. dan Can, N., 2012, Measurements of Enviromental Pollution in Industrial Area Using Magnetic Susceptibility Method, Proceeding of International Congress on Advanced in Applied Phisics and Materials Science, Vol. 121, hal. 20-22.

Mindasari, L., 2007, Dampak Kegiatan pertambangan Batubara PT. Tambang Batubara Bukit Asam (PT.BA) TBK- Unit Produksi Ombilin (UPO) dan Tambang Batubara Tanpa Izin (PETI) terhadap Kualitas Air Sungai Batang Ombilin, Skripsi, Fakultas Kehutanan, Institut Pertanian Bogor, Bogor.

Odat, S dan A.M. Alshammara. 2011. Seasonal variations of soil heavy metal contaminants along urban roads: A case study from City of Hail, Saudi Arabia, Jordan Journal of Civil Engineering,Vol. 5(4), hal. 581-591.

Palar, H., 2004, Pencemaran dan Toksikologi Logam Berat, Rineka Cipta, Jakarta. 
Purba,I.Y.S., Izmiarti, Solfiyeni., 2015, Komunitas Algae Epiliptik Sebagai Indikator Biologis Di Sungai Batang Ombilin Sumatera Barat, Jurnal Biologi Universitas Andalas, Vol. 4(2), hal. 138-144.

Rochyatun, E dan Rozak, A., 2007, Pemantauan Kadar Logam Berat dalam Sedimen di Perairan Teluk Jakarta, Makara Sains, Vol. 11 (1), hal 28-36.

Sudarningsih., Lestiana, E dan Wianto, T., 2013, Analis Logam Berat Sepanjang Daerah Aliran Sungai (DAS) Tabalong Kalimantan Selatan, Prosiding Semirata FMIPA Universitas Lampung, Lampung.

Sudarwin, 2008, Analisis Spasial Pencemaran Logam Berat ( $\mathrm{Pb}$ dan $\mathrm{Cd}$ ) pada Sedimen Aliran Sungai dari Tempat Pembuangan Akhir (TPA) Sampah Jatibarang Semarang, Tesis, Program Pasca Sarjana, Universitas Diponegoro, Semarang.

Wahyuni, T.R., Zulaikah, S., Sutrisno., Kurniawan, H.C. dan Mayangsari, S.,2015, Kajian Sifat Magnetik dan Kandungan Logam Berat pada Sedimen Mangrove Wonorejo Surabaya, Journal of Physical Science and Engineering, University Negeri Malang.

Wang, J., Sun, Q., Yi, L., Yin, X., Wang, A., Li, Y., 2014, "Spatial Variation Environmental Assasment and Source Identificationon Heavy Metal in Sedimentof The Yangtze River Estuary", Marine Pollution Bulletin, Vol 64, Elsevier, hal. 364-373.

Xu, Y., Chen, F., Zhang, L., Liu, J., Shen, Z., Feng, C and Chen, J., 2014, The Source of Natural and Anthropogenic Heavy Metal in The Sediment of minjiang River Estuary Science Total Environ, Vol 493, Elsevier, hal. 729-736.

Yulius, U. dan Afdal, 2014, Identifikasi Sebaran Logam Berat pada Tanah Lapisan Atas dan Hubungannya dengan Suseptibilitas Magnetik di Beberapa Ruas Jalan di Sekitar Pelabuhan Teluk Bayur Padang, Vol. 3, No. 4,Jurnal Fisika Unand,hal. 198-204. 